\title{
最近の珪酸鉱物に関する知識 (3)
}

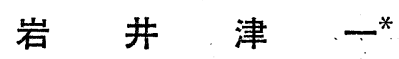

前回の資料最近の理酸鉱物に関する知識 (1) そ括い ては珪酸鉱物の新しい相の紹介，(2) に和いては主と してトリジイトならびマクリストバライトの諸特性 の多様性と, 結晶構造の異常性の記述を構造多形の見 地からなした.この (3) 飞颃いては, 主飞石英, トリ シマイト括よびクリストバライト等の珪酸鉱物の転移 (Inversion) 飞関する問題についての比較的新しい知 識を紹介して見ようと思う。

一般に，珪酸鉱物のような複雑な現象を伴う多形転 移は, 転移反応の難易を支配する構造の不整の度合 と, 諸物理化学的特性とを包含した平衡問題として, 広い熱力学的見地から解明されるべき問題であるが, ここでは主として結晶学的立場から見た珪酸鉱物の相 転移について述べて見る。

新しい相の転移については, 資料 (1) 飞和いて大略 記述した。石英, トリジマイト括よびクリストバライ 卜飞関する最近の平衡関係の純勢力学的知識は'M.A. $\mathrm{Moseman}^{5}$ 外の研究を，またクリストバライトとトリ シマイトの格子ェネルギーの理論的算出による安定不 安定の閱題は, 資料 (2) で少し触れた S.N. Ruddles$\operatorname{den}^{46)}$ の論文を参照されたい。

\section{3. 珪酸鉱物の転移}

1950 年飞 M.J. Buerger ${ }^{47)}$ "Crystallographic Aspects of Phase Transformations" という 論文の中で結晶物質の転移に関す る知見を取りまとめて，結晶の転 移を構造の変化と転移の速度によ り分類している．ここにこれを簡 単飞要約して紹介する.

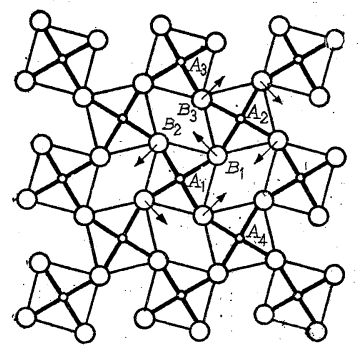

b 順

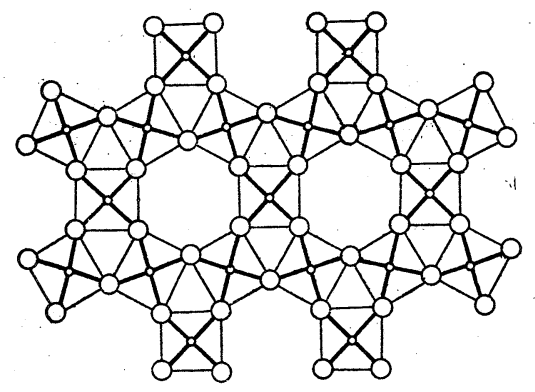

a

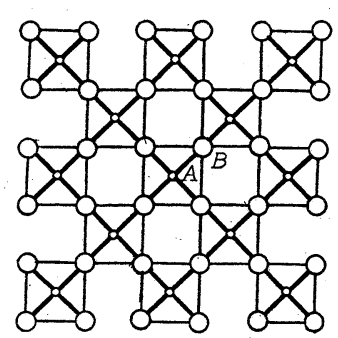

第
M.J. Buerger そよる結晶の転移の分類（1950年）

1）二次配位の転位（網目構造の転移）

(a) 変位型 (高温型一低温型間速い)

(b) 再編型 (遅い).

2) 乱れの転移

(a) 回転型 (速い)

(b) 置換型（遅い）

3) 一次配位の転移

(a) 脹膨型 (速い)

(b) 再編型 (遅い)

4) 結合型の転移（通常遅い）

次に，以下これらを簡単に説明する。

1) 二次配位の転移 二 二次配位の転移 (Transformation of secondary coordination) といるのは, 結晶体を構成する原子の本来の配位数には変化がな く, 全体として構造湾化が起るような転移で，これ は網目構造を有する結晶物体と和いて見られるので, 網目転移 (Network transformation) ともいう.

(a) 変位型 二次配位の転移の内で変位（Displacive) の転移というのは，招互に相接している原子 の接触は保持されたままで，相接していない原子は招 互に変位して，その結果全体とし て構造が歪められるような変化を する転移.

この変化の様子を平面的模型で 第 24 図に示す. 同図治いて, cに対してbあるいはdのような 変化がこれに相当する。 bとd と は和互に順, 逆の関係にある。

この種の転移の特徽は, 転移に 際して網目の結合は終止破れるこ

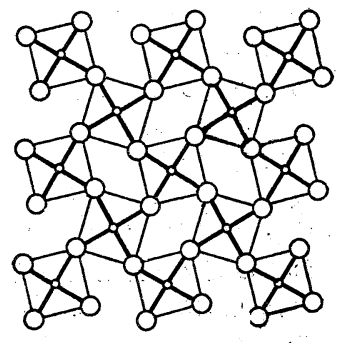

d 逆

* 東京工業大学 
とがないので，このような変化とは活性化エネルギー をほとんど必要としない, したがってとの種の転移の 速度は通常極めて速やかである.

理酸鉱物特よび同形 (Isomorph) の $\mathrm{AlPO}_{4}$ の高温 ・低温型 $(\alpha \cdot \beta$ 型間) の転移が代表的な例である.

この種の転移に甜いて, 高温型のものは低温型のそ れ飞比ベて, より吵間の多い構造 (Open form) で, 密度はより小さく, かつより大きな熱容量をもってい る. したがって後者は前者に対して多少畳まれた構造 (Collapse form) ともい方る.また高温型の構造は低 温型飞比べてより高い対称性を有し，一般て後者の空 間群は前者の下群 (Sub group) 飞属するるのである.

高温型の構造より低温型のそれに移行する場合には しばしば複雑な双晶を生じる。これは, 上記の順逆の 二つの型の起る確率が同じであることが原因の一つで めろろ.

(b) 再編型 再編の転移(Reconstructive transformation) といろのは, 一番近いところにある原子 の配位は変化しないが，さらに遠いところとある原子 の位置は相当飞変化する転移で, 網目構造のある程度 の再編成が必要である. この点で (a) とは根本的飞異

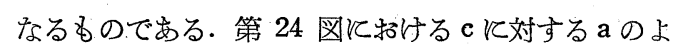
ろな変化で, このような転移が起るためとは, 元の構 造の一次の配位は一たん破れて，小さな小片と分解し， ふたたび新しい構造を構成することとなる." この種の 転移には比較的高い活性化エネルギーが必要で，した がってての転移はゆるやが起るのが普通である.

代表的な例としては, 石英, トリジマイト, クリス トバライト間の転移招よび $\mathrm{AlPO}_{4}$ のとれらに相当す る相間の転移に知られている。

2) 乱れの転移 乱れの転移(Transformation of disorder) は近年飞゙至って注意されるようとなったい わゆる二次転移飞属する非古典的転移* (Non classical

* 上記の分類に牱いて，2)を除く他の転移の形式は 従来より知られている古典的の転移 (Classical invers.) で転移飞際しては周知の如く Clausius Clapeyron の式にしたがう潜熱現象を伴って, 熱 力学的函数エントロピー $S$ や体皘 $v$ 等は不連続 的 jump を示す。とれらの量は Gibbs の自由エ ネルギーの温度, 圧力に対する一次微分量である ので一次の転移と称せられる。

2)の転移の形式は, 近年飞至って注意されるよ らとなったるので, その転移飞際して潜熱現象が なく, 自由エネルギーの三次微分量である比熱 $C_{\boldsymbol{b}}$, 熱膨脹等飞不連続的な变化を示すすので, そ れらの変化は普通転移点の少し下から徐々飞始ま り，次第飞增大して転移点に括いて最高飞達し転 移後は急激減衰して, その形がギリシャ文字の 入の字飞似ているところから入転移とも称せら れる。この種の転移の前後には構造的な変化はあ まりなく，X線等で検出し得ない場合が多い。 invers.) である.

(a) 回転の転移、回転の転移(Rotational invers.) は構造中の原子団である基イオンあるいは分子の回 転, るしくは束縛された回転によるるの. その転移の 速度は一般速やかである. $\mathrm{NH}_{4}$ や $\mathrm{CN}$ イオンの例 が知られている。

(b) 置換の転移 置換の転移 (Substitutional invers.) は, 構造中の原子の自己拡散によるもので, 代 表的な例として斜長石 $\mathrm{NaAlSi}_{3} \mathrm{O}_{8}-\mathrm{CaAl}_{2} \mathrm{Si}_{2} \mathrm{O}_{8}$ 系の固 溶飞招いて $\mathrm{Na}\left|\mathrm{Si}_{3} \mathrm{Al}\right|$ 群と $\mathrm{Ca}\left|\mathrm{Si}_{2} \mathrm{Al}\right|$ 群との置換の 規則性と不規則性の現象として知られている。 この際 三次元網目の結合は一度破れなければならないので， 大きな活性化エネルギーが必要であり, 長石の場合で は, その速度は遅い。

3) 一次配位の転移

明らかと配位数の異なる 2 形間の転移で,

(a) 膨脹型 体心格子の面心格子への移行. 例, $\alpha \mathrm{Fe}-r \mathrm{Fe}$

(b) 再編型 例, 方解石一心られ不の転移.

4）結合型の転移、転移によって原子の結合様式 飞変化の起るもの.

例, ダイヤモンドー石畦の移行:

上記の M.J. Buerger の分類によると, 珪酸鉱物の 転移は大略 1) の二次配位の転移飞該当するるのであ ると考学ることが出来る。しかし一般に1つの転移現 象は, 上記の分類のぞれか一つに必ずしもぴったりあ てはまるものではない．例党ば二次配位の変位の転移 である高低温型の転移飞際して 4).の結合型の転移が 伴なわれ，高低に移るときと結合様式は多少イオン性 から共有性飞変化する。

次に, 理酸鉱物の各相の高低温型転移と各相間の転 移とついて，個々の相とついて知られているととを述 ベて見る.

\section{石英の高温型一低温型間の転移}

上記の分類で, 二次配位の変位型て属する極めてて速 度の速い転移である。まず転移点の温度は, 資料(2) そ执いて子触れたようと，O.F. Tuttle ${ }^{48}$ らの研究に よると天然産の石英では $573^{\circ} \mathrm{C}$ 付近でその值に 1.90 ${ }^{\circ} \mathrm{C}$ 程度の変動が知られている。た特殊な例として ニュージランド産のある種の粘土に伴なう石英は $573^{\circ}$ C の鋭いピークの外飞, $555^{\circ} \sim 560^{\circ} \mathrm{C}$ 間にゆるやかな ピークを示すことが報じられている：人造の石英につ いて底 M.L. Keith ${ }^{49}$ らの研究によると Ge を含むる の庄その転移点が $40^{\circ} \mathrm{C}$ 高くなり，Li とAl の入っ たものは $120^{\circ} \mathrm{C}$ 低くなるととが報告されている。 た興味ある事実は，R. Roy ${ }^{50}$ ： ら研究である.すな わち石英に少量のリチウム理酸塩を混入することによ 
って高温型の構造を室温に安定化させることが出来た といら事実である。またこの.よ.うな異常は W.F. Bradley ${ }^{51)}$ がある種類のモンモリナイトを焼成して得 られた石英が高温型のるのであると報じている.

石英の高温型の安定化の問題は, 転移の際の大きな 熱膨脹に関連して工業的に大きな意味を持つものであ ろろ.

R.D.E. Mandrof ${ }^{52)}$ 飞よると, 単結晶の, 石英転移の 温度が厚い試料と薄心試料とでは，先の温度の上昇と 下降の場合に異なる事実が報ぜられている。

石英の低温型から高温型への転移に招いて，従来か らその転移点の上下で比熱曲線, 熱膨脹曲線に急激な 折れ曲りが認められ，転移点の下で徐々に変化する入 型の現象が知られている. これとついて, 外は, F.C̣. $\mathrm{Kraeck}^{53)}$ らは石英が上記のような比熱の変化の 仕方 と一方高温型は低温型と明らかに異なった対称を示す 事実奻地；石英の転移は二次の転移と一次の転移の 混合した例であるとの見解を述べている.

この石英の転移についての本質的な性質の研究は, C.V. Raman ${ }^{54)}$ らにより進められている. 彼らは石英 を液体空気の温度より転移点まで加熱した際に観測さ れる, 単色光のスペクトルの変化から, 特殊の型の振 動が励起されることを認め，これは石英の原子の配列 が一部破壊されるのであるとの結論を得ている。この 考察を H.S. Allen ${ }^{55)}$ はさらに進めて, これは転移の 上下の 2 つの相に固有な振動の共振であることを示し ている.

次に，高温型の石英についての特異な性質として， 石英は転移点以上の温度に括いては；各軸共に負の膨 脹係数を有することが知られているが，この説明とし て, H.T.Smyth ${ }^{56)}$ は, 酸素の振動数が構造が膨脤す るにつれて増加するためね, 負の膨脹を示すのである としている。

\section{クリストバライトの高温型一低温型間の転移}

クリストバライトは石英と同じく二次配位の高低温 型転移をする，高温型は等軸の対称，低温型は正方の 対称を示す，その転移の温度は, 生成の熱の歴史と外 囲の状沅により大いに変化することは資料 (2) の示差 熱分析曲線によっても知ることができる，一般に生成 温度の高い，格子不整の程度の少いもの䚾ど高い転移 点を示し, 従来知られている転移点の最高温度は $270^{\circ}$ 〜275 ${ }^{\circ} \mathrm{C}$ である. ところが，その生成条件から判断し て，構造に格子不整を伴なっていないと考光られるク リストバライトで, 転移点が $218^{\circ} \mathrm{C}$ と $226^{\circ} \mathrm{C}$ のもの が報告されている。これにういては, O.W. Flörke ${ }^{57) *}$ はクリストバライトの転移点の移動には 2 つ因子が

\footnotetext{
* 本誌, 65 [736] 93 (1957)
}

考えられ，1つは四面体層の積み重なりの不整で；格 子不整の多いものは転移は低い温度で始まり漸次進子 ゆるやかな体積変化をする. 他の一つは格子間飞存在 する他元素イオンの影響でこの場合は転位温度は低く なるが，膨脹は乱れのないクリストバライトと同様に 急激㲹起ると述べている.

クリストバライトの転移について興味深い事実は, 従来からある種の蛋白石, ある種のガラスに含まれた クリストバライト及びベントナイトの中に含まれてい るものが, 室内に括いても高温型のものとして認めら れることが報ぜられていることである. この問題につ いて M.J. Burger ${ }^{47}$ は, ごれらのクリストバライト の結晶粒子が小さいためと，その表面が高いエネルギ 一状態に保たれていてその結果, 転移がさまたげられ ているのであるとの見解を述べている. また O.W.

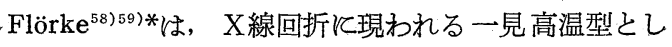
て認められるクリストバライトは, 低温型の極度に格 子不整の多いものであるとの見解を述べている. 著者 $ら^{60)}$ このような高温型のクリストバライトをある種 のシャモット中に見出したが，この場合上記の解釈の 外飞, 他イオンが構造の隙間の中に入り込んだために 転移がさまたげられているのではないかと考察した。

次に, クリストバライトの熱膨脹に関する知見とし て, 高温型のクリストバライトは, R.B. Sosman ${ }^{2)}$ そ よると $800^{\circ} \mathrm{C}$-付近に和いて熱膨脹の最大值を示すと報 ぜられているが，W. Johnson ${ }^{61)}$ ら**の最近の研究は この事実が認められなかったことを報じている。

クリストバライトの転移に関する微構造的研究とし ては, W. Niewenkamp ${ }^{30)}$ が高温型の構造に括いて は, その珠酸素四面体の 酸素の回転*** を提案してい る.これは一応見事な成果であるが，実際の転移現象 はさらと複雑なるので, 石英と同じようにはっきりと した構造の変化も起ると同時に乱れの変化を伴なろ一 次・二次転移の混合したものであろろと考えられる。 が，その乱れの本質は不明である。

著者ら****は高温X線の実験で，石英を $1600^{\circ} \mathrm{C}$ に かなり長く保って得たクリストバライトが転移後の $300^{\circ} \mathrm{C}$ 付近と $500^{\circ} \mathrm{C}$ 付近とでは, その回折線 $(220)$ の強度がかなり変化することを認めたことがある.こ れは,クリストバライトの高温型の構造に, その転移 の直後にはかなりの乱れが存在するものと想像される が，この現象がどの試料でもかならず起こるものか, また再現的に起こるものであるかという点はまだ充分 に確かめていない.

\footnotetext{
* 本誌, 64 [732] 291 (1956)

** 本誌, 64 [729] 231 (1956)

****資料 (2) 18 図参照

****末発表実験データ

***** 著者未発表
} 
これと関連して, 著者*****の見解として X 線とよ るクリストバライトの定量の問題について触れて見 る. O.W. Flörke ${ }^{17)}$ は, クリストバライトの構造には 一次元格子不整が伴なうので, その回折線の強度は変 化し, したがってこの回折線の強度による定量は不可 能であると述べているが，著者は少なくとも(111) 面 の強度に関する限り, 必ずしもとうでないという結果 を反射強度の計算から得て括り,クリストバライトは X線による定量が可能であると考えている.

\section{トリジマイトの高温型低温型間の転移}

いわゆるトリジイマイト（二層構造の勝れたもの） といわれるもののこの転移は, 石英やクリストバライ トに比較してさらに複雑で, かつ基本構造がはっきり 解析されていないので，その詳細は不明である。転移 点には各種のものが知られていることは資料(1)のト リジマイトの新相のところでも述べた。 またこれは資 料(2)のトリシマイトの示差熱分析曲線によってる知 ることが出来る.

ここには, A.E. Dodd"1)の “The Forms of Silica” ね集録された, 各種のトリジマイトの転移点を示す.

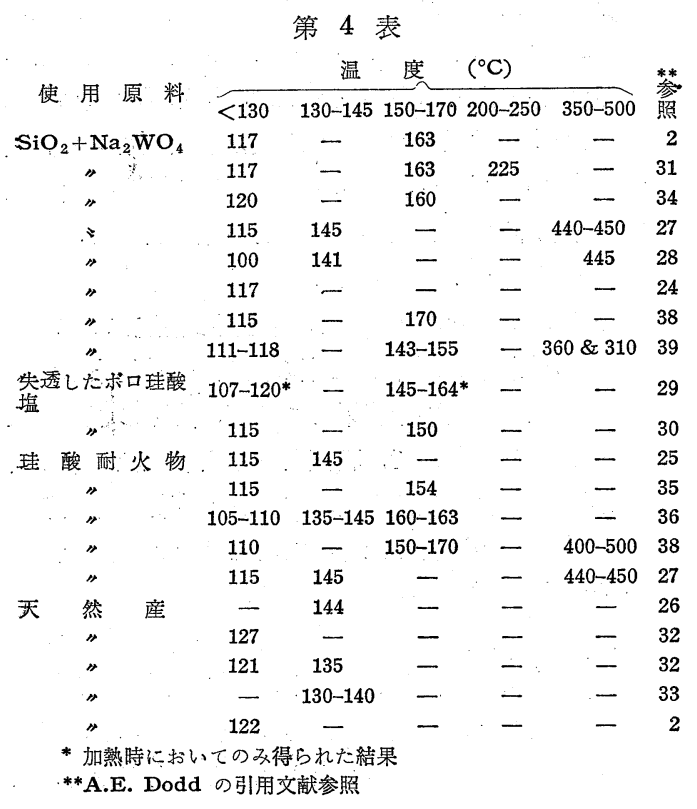

石英とクリストバライト，トリジイマイト間の転移 石英とクリストバライト，トリジマイトと相互の 転移は前記の分類によると二次配位の再編型の転移で せりそ転化のためには一時的に Si-O の結合を一 部破らなければならないので，これらの転移の速度は 一般遅いものである.

周知のよう飞，石英を単独にかなり高い温度に加熱 しても容易とクリストバライトやトリジマイトと変化 しない。しかしこれと適当な鉱化㓮 (Mineralizer)を
添加すると，この反応の速度を大いと早めることが出 来る、例党ば，鉱化剤を使用しないで石英を $1550^{\circ} \mathrm{C}$ 飞 2 時間加熱した場合より，1.5\%の $\mathrm{Na}_{2} \mathrm{O}$ と $1.5 \%$ の $\mathrm{Fe}_{2} \mathrm{O}_{3}$ よりなる複合鉱化剂を使用して $1400^{\circ} \mathrm{C} て ゙ 2$ 時間加熱した方が，より多くのクリストバライトを得 られた例がある。

珪酸釷物江対する鉱化剂の機構飞関する研究は, 従 来から多くの研究者によりなされているが、ここにそ の二, 三を拾って見る. N.W. Taylor ${ }^{62)}$ 外は近年; 石 英飞関する種々の実験から，.鈗化剤の効果は，液体の 状態にあるとき效果的であり, $870^{\circ} \mathrm{C}$ 以上の温度に和 いては石英は不安定であるので液状の 鉱化剈飞熔解 し，その中から安定なクリストバライトが沈澱すると

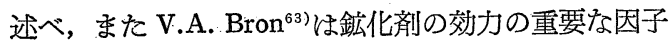
としてはその流動性であり，一般とガラスを形成する 能力の多以物質は有效であると述べている.

N.N. Sinel'nikov*64) は石英のトリジマイト化の反 応速度の研究に扮いて， $\mathrm{Li}_{2} \mathrm{CO}_{3}$ を使用したときと, 石英の粒径と鉱化剂の量並びて転移の速度には一連の 関係が存在するものであることを述べ，ちょうど粒子

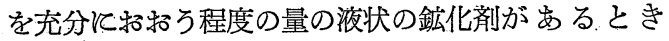
飞,トリシィマイト化が最大となり，同量の鉱化㓮の 場合は粒子がある程度以上小さくなるととの比表面積 が大きくなるためと転移速度は減少し，逆に粒子があ まり大きくて子転移の速度は減少する，末たある程度 以上の量の鉱化剂を加えてる反応速度は增大しなかっ たと報告している。

鉱化剂飞関する新しい結晶化学的立場からした基本 的な解明は W.A. Weyl らとより進められいるが，こ れとついては. W. Eitel の成書等を参照されたい.

以上で著者の珠酸鉿物の資料は終りであるが，珪酸 鉱物々関する新しい知識としては, 珪酸鉱物と構造的 そ同形の関係にある鉱物の問題，放射線による珪酸鉱 物の結晶破壊の問題, $\mathrm{SiO}_{2}-\mathrm{H}_{2} \mathrm{O}$ 系の問題等の重要な 事項があるが、これについてはここでは触れなかった。

終りに, 著者らの研究飞対して, 有益な教示と示唆 を賜わったドイッの O.W. Flörke 博士に感謝の意を 表する。

付記：資料 (1) のコェサイト (Coesite) の発音とつい て,ペンシルバニア大学の小泉光恵さんよりの私信 でコーザイトと発音するのが正しいとのご教示をい ただいた。

$$
\text { 文 献 }
$$

47) M.J. Buerger, Phase Transformation of Solid, Smolchowsky, ed., J. Wiley \& Sons, New York (1950)

48). O.F. Tuttle, Amer. Mineral., 34, 723(1949) 49) M.L. Keith and O.F. Tuttle, Amer. J.Sci., 
Bowen Vol.1, 203 (1952)

50) R. Roy and E.F. Osborn, J. Am. Chem. Soc., 71, 2089 (1949)

51) W.F. Bradley and R.E. Grim, Amer. Mineral., 36, 182 (1951)

52) R.D.E. Mandrof, Hev. Physica Acta, 22, 579 (1949)

53) F.C. Kraeck, J. Am. Chem. Soc., 53, 2609 (1931)

54) C.V. Raman and T.M.K. Nedungodi, Nature, London, 145, 147 (1940)

55) H.S. Allen, ibid., 145, 306 (1940)

56) H.T. Smyth, J. Ceram. Soc., 38, 140 (1955)

57) O.W. Flörke, Ber. deut. Keram. Ges., 33
[10] 319 (1956)

58) O.W. Flörke, Naturwiss., 16, 371 (1954).

59) O.W. Flörke, Neu. Jahr. für Mineral., 10, 217 (1955)

60) M. Ōmure, S. Ookawara und S. Iwai, Naturwiss., 21,495 (1956)

61) W. Johnson and K.W. Andrews, Trans Brit. Ceram. Soc., 17, 227 (1956)

62) N.W. Taylor and C.Y. Lin, J. Amer. Ceram. Soc., 24, 57 (1941)

63) V.A. Bron, Doklady Akad. Nauk S.S.S.R., 59, No.3, 535 (1948)

64) N.N. Sinel'nikov, Trans. Brit. C.S. Abst., 137 A 986
製 品紹介

真空高周波電聯炉金属熔解用大型 電融マグネシア坩堝の製造に成功

近事とみに需要の高まってきた純金属，合金の製造 に不可欠な真空高周波熔解用坩堝としては, 従来ノル トン社製品がもっぱら使用されてさたが，日本化学陶 業株式会社では過去 1 年有余の研究の結果, 最も難事 とされていた大型畤堝 $(50 \mathrm{~kg})$ の成形战到し，こ

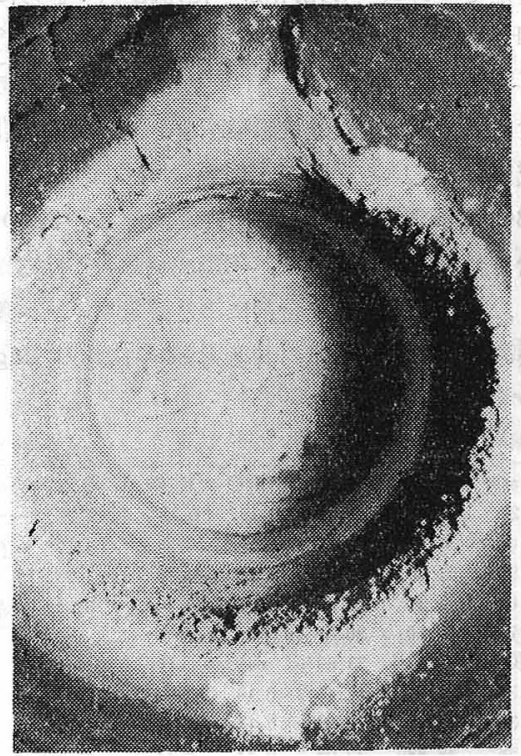

22 回使用

\begin{tabular}{|c|c|c|}
\hline & 坩 堝 & 特 性 \\
\hline & $\mathrm{MgO}>96 \%$ & 比 熱 \\
\hline 嵩此重 & 2.72 & $20 \sim 500^{\circ} \mathrm{C} \sim 0.259 \mathrm{Kcal} / \mathrm{kg}^{\circ} \mathrm{C}$ \\
\hline 孔率 & $23.10 \%$ & 熱膨掁係数 \\
\hline 水率 & $8.30 \%$ & $0 \sim 900^{\circ} \mathrm{C} \sim 11.2 \times 10^{-6} \Delta 1^{\circ} / \mathrm{C}$ \\
\hline 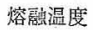 & $>2500^{\circ} \mathrm{C}$ & \\
\hline
\end{tabular}

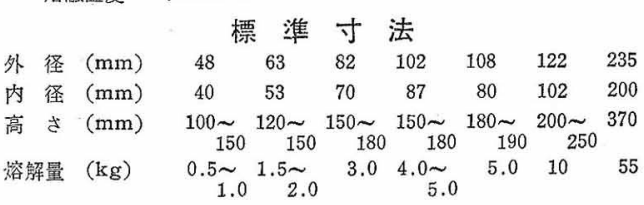

れまで常に供給上の不安に检京されていたわが国の 冶金技術界に対し安定した製昆る供給することが可能 となった.

従来ノルトン社製のものを使用していた住友金属工 業株式会社では同社製 $50 \mathrm{~kg}$ 月大型電融マグネシア坩 堝について $\mathrm{Ni}, \mathrm{Ni}-\mathrm{Fe}$ 合金等の 高周波真空熔解を行 った結果，連続 44 回の反復使用に充分酎方うること が証明され，而侵蝕性の点でも先の優秀性が実証され た。 また，京都大学冶金学教室でもこの坩堝の生座化 によって研究上多大の便宜を得ているとのことであ る. 図は艺のときの使用状態の写真である.

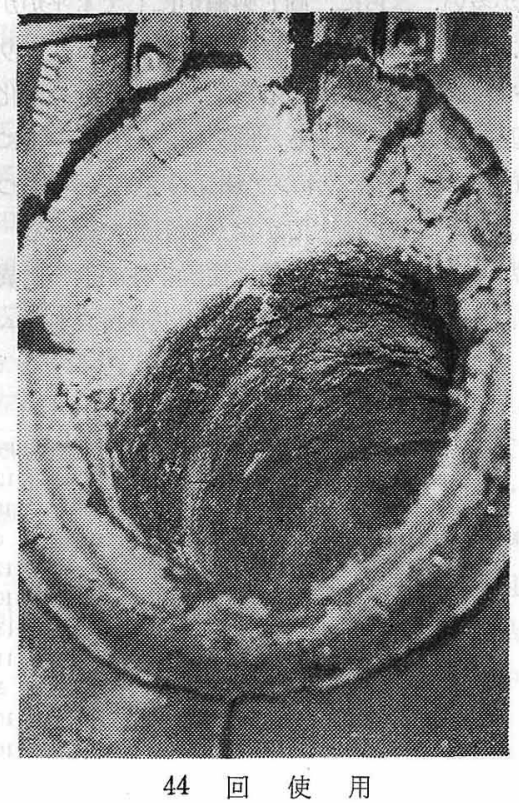

な呿同社製電融マグネシア坩堝の特性を示すと左記 の通りである.

1 個当りの值段は $48 \times 40 \times 150 \mathrm{~mm}$ で 900 円， 102 $\times 87 \times 180 \mathrm{~mm}$ で 3000 円で岕る. 引合先は C C マーク の日本化学陶業株式会社大阪営業所（大阪市東区高麗 穚 2 の 52 電話(23)1414), 九州営業所 (湢岡市大学通り 1046 電話(3)3423), 西村工業株式会社（東京都干代 田区神田旭町 6 電話(25)3123) につきど照介下さい. 